\title{
A Comparison between Both Mineralocorticoid Receptor Antagonist Agents (Eplerenone and Spironolactone) in Prognosis of Heart Failure with Reduced Ejection Fraction (HFrEF) \\ Mohamed Ayman Mostafa Saleh, Ramadan Ghaleb Mohammed, Ayman Maher Asham Ibrahim, Mena Mekhail Solhy* \\ Department of Cardiology, Faculty of Medicine, Aswan University \\ *Corresponding author: Mena Mekhail Solhy, Email: menamekha88@ gmail.com
}

\begin{abstract}
Background: heart is the target organ for Aldosterone, spironolactone and eplerenone (mineralocorticoid receptor antagonists) inhibits the aldosterone extraction through the heart in patients with congestive heart failure (CHF). Objective: to evaluate prognostic impact of both MRA (spironolactone and eplerenone) on heart failure and compare between both agents in incidence of side effect (gynecomastia and hyperkalemia).

Patients and Methods: the study was conducted from March 2016 to September 2016 at Aswan University hospital. Our study population consisted of 100 adult patients, who were proved to have heart failure symptoms, with reduced ejection fraction heart failure divided in two groups. Group A contains 50 patients on spironolactone in addition to other anti-failure treatments according to ESC guidelines. Group B is 50 patients on eplerenone in addition to other anti-failure treatments according to ESC guidelines.

Results: follow up had been done after one month for patient clinical status and serum potassium level and development of gynecomastia. Another Follow up was done after 3 months for BNP level, gynecomastia, NYHA classification and body weight.

Conclusion: MRA are important line of treatment in HF patients, eplerenone and spironolactone are both have good result in improving BNP level and improving NYHA classifications and patients weight loss.
\end{abstract}

Keywords: Mineralocorticoid receptor, atrial fibrillation, congestive heart failure.

\section{INTRODUCTION}

Until recently, our understanding of aldosterone focused on its effects on sodium, water retention and potassium excretion, which are mediated by the binding of aldosterone to the mineralocorticoid receptor (MR) in epithelial tissues, such as the kidney and non-epithelial tissues, such as the heart, brain, and vasculature $^{(\mathbf{1})}$.

These actions are associated with adverse effects, including impaired synthesis of the vasodilator nitric oxide; promotion of vasoconstriction, endothelial dysfunction, inflammation, and fibrosis in vasculature which reflect as ventricular hypertrophy, collagen deposition and remodeling in the heart ${ }^{(\mathbf{1})}$.

Currently, two agents are available that competitively inhibit aldosterone at the MR: spironolactone and eplerenone. Spironolactone is associated with progestogenic and antiandrogenic adverse effects. Eplerenone is a spironolactone derivative designed to enhance selective binding to the MR while minimizing binding to progesterone and androgen receptors ${ }^{(2)}$.

RALES and EPHESUS studies have shown that this "aldosterone breakthrough" is an important factor because it is a determinant of outcome in heart failure patients. Therefore, it may be beneficial if the therapies employed were downstream of this system specifically at the $\mathrm{MR}^{(3)}$.

Understanding of the adverse pharmacological

properties of aldosterone has prompted investigation of the clinical benefits of blocking aldosterone at the receptor level.

\section{AIM OF THE WORK}

To investigate the safety, relative efficacy and side effects of different oral doses of spironolactone \&eplerenone in prognosis of heart failure patients.

\section{PATIENTS AND METHODS}

I. Study Design: This study is an observational study that was recruited patients diagnosed as heart failure with low ejection fraction.

II. Setting: Recruitment was in Cardiology department, Aswan University, Aswan, Egypt.

III. Sample size: One hundred patients as (50 patients in spironolactone group \& 50 patients for eplerenone group)

IV. The inclusion criteria: The Patients with HF according to Framingham criteria with EF equal or less than $40 \%{ }^{(4)}$.

\section{Framingham criteria ${ }^{(4)}$ :}

Major criterion: Paroxysmal nocturnal dyspnea. Neck vein distention. Pulmonary Rales. Radiologic cardiomegaly. S3 gallop. Increased central venous pressure. Hepatojugular reflux. Weight loss $>4.5 \mathrm{Kg}$ in5 days in response to treatment.

Minor criterion: Bilateral ankle edema. Dyspnea on ordinary exertion. Hepatomegaly. Pleural effusion. Decrease in vital capacity by one third of maximum recorded. Tachycardia (heart rate $>120 \mathrm{~b} / \mathrm{min}$ ). 
Diagnosis of Heart Failure requires presence of at least 2 major criteria or one major criterion in conjunction with 2 minor criteria.

The Framingham Heart Study criteria are $100 \%$ sensitive and $78 \%$ specific for identify person with definite HF.

V. The Exclusion criterion: Estimated $\mathrm{CrCl}$ less than $30 \%$, serum K+> 5meq. Disease of the gastrointestinal tract which may interfere with the absorption, pharmacokinetics or elimination of the study medication. Severe Co-morbid condition expected to lead to death within one year. Renal failure. Liver cell failure. Sepsis.Hypersensitivity from drug material.Pregnancy. HFrEF due to significant valvularlesions (more than mild primaryvalvular heart disease).

\section{Written informed consent:}

An approval of the study was obtained from Aswan University academic and ethical committee. Every patient signed an informed written consent for acceptance of the study.

\section{Methodology:}

\section{All patients will be subjected to:}

A) Clinical evaluation: History, physical examination, and body weight.

B) Electrocardiography (E.C.G.): To detect rhythm, rate and any ischemic changes.

\section{C) Echocardiography:}

Echocardiography examination was performed by using Philips IE 33@ machine with simultaneous ECG tracing within 24 hours from admission. Images were obtained by a single experienced operator blinded to clinical and biochemical information. In short, LVEF was obtained according to Modified Simpson's rule ${ }^{(5)}$, or M-mode technique ${ }^{(6)}$. Cardiac chambers diameter and volume. Diastolic dysfunction. Regional wall motion abnormalities. Valves morphology and flow.

D) Plain chest X-ray: For pulmonary Rales, X-ray cardiomegaly and pleural effusion.

D) Blood sampling for all candidates: Blood sampling procedures and assay of serum BNP level from peripheral vein samples were gotten after written informed consent within 24 hours of admission. Analysis of BNP was executed using (Ab193694 BNP Human ELISA Kits For quantitative measurement of Human BNP in serum, plasma and cell culture supernatants) immediately after blood sampling. In addition, routine biochemical work-up was performed including creatinine, hemoglobin, sodium, potassium and cardiac enzymes during the hospital stay. Estimated glomerular filtration rate (eGFR) was measured using Cockcroft-Gault formula. Starting add spironolactone $25 \mathrm{mg}$ to half of the patient and eplerenone $25 \mathrm{mg}$ to the other half (According to their serial numbers).

Example: odd figures $(1,3,5,7$, Etc) for spironolactone group \& doubled figures as $(2,4,6,8$, Etc) for eplerenone group.

E) Follow up: Follow up after one month for: Symptoms, signs \& NYHA classification of heart failure patients. Breast enlargement or mastalgia (for gynecomastia) in the male patients. Follow up potassium level (for hyperkalemia) ${ }^{(7)}$. If potassium level below $5 \mathrm{mEq} / \mathrm{L}$, we would increase the dose of spironolactone to $50 \mathrm{mg}$ daily (divided on two doses), and epelernone to $50 \mathrm{mg}$ once daily.

Follow up after three months for: Serum BNP level (by the same previous technique). Symptoms, signs \&NYHA classification of heart failure patients. Breast enlargement or mastalgia (for gynecomastia) in the male patients.

The end points of the study were: All-cause mortality Worsening heart failure/need for rescue therapy: In-hospital WHF was defined as unresolved or recurrent symptoms and signs of $\mathrm{HF}$ that required an increase in or institution of intravenous HF-specific therapy, or institution of mechanical ventilator or Circulatory support. Hyperkalemia (increase of serum potassium above $5 \mathrm{mmol})^{(7)}$.

\section{Statistical Analysis}

Data were collected, revised, coded and entered to the Statistical Package for Social Science (IBM SPSS) version 23. The quantitative data were presented as mean, standard deviations and ranges while qualitative variables were presented as number and percentages.

The comparison between groups regarding qualitative data was done by using Chi-square test and/or Fisher exact test when the expected count in any cell found less than 5 .

The comparison between two independent groups with quantitative data and parametric distribution was done by using Independent t-test.

The comparison between two paired groups with quantitative data and parametric distribution was done by using Paired t-test.

The confidence interval was set to $95 \%$ and the margin of error accepted was set to $5 \%$. So, the p-value was considered significant as the following: P-value $>$ 0.05: Non significant (NS). P-value $<0.05$ : Significant (S). P-value < 0.01: Highly significant (HS)

\section{RESULTS}

According to demographic characteristics, there were no significant differences between both groups in age, gender or body weight (Table 1). 
Table (1): Demographic characteristics of patients:

\begin{tabular}{|c|c|c|c|}
\hline & $\begin{array}{c}\text { Spironolactone group } \\
\mathrm{N}=\mathbf{5 0}\end{array}$ & $\begin{array}{c}\begin{array}{c}\text { Eplerenone group } \\
\mathrm{N}=50\end{array} \\
\end{array}$ & P-value \\
\hline $\begin{array}{l}\text { Age (in years) } \\
\text { Mean } \pm \text { SD }\end{array}$ & $55.5 \pm 13.3$ & $57.6 \pm 12.4$ & 0.418 \\
\hline \multicolumn{4}{|l|}{ Sex: Freq. (\%) } \\
\hline Males & $39(78 \%)$ & $40(80 \%)$ & 0.806 \\
\hline Females & $11(22 \%)$ & $10(20 \%)$ & \\
\hline $\begin{array}{l}\text { Body weight (in kg) } \\
\text { Mean } \pm \text { SD }\end{array}$ & $85.3 \pm 13.6$ & $81.1 \pm 13.4$ & 0.183 \\
\hline
\end{tabular}

$\mathrm{P}$ value $<0.05$ was considered statistically significant, SD: standard deviation

There was no significant difference between both groups as regard neck vein distension $(\mathrm{P}$ value $=0.4), \mathrm{S} 3$ gallop $(\mathrm{P}$ value $=0.5)$, sinus tachycardia $(\mathrm{P}$ value $=0.13)$, hepatomegaly $(\mathrm{P}$ value $=0.08)$ and ankle edema $(\mathrm{P}$ value $=$ 0.40). (Table 2)

Table (2): Comparison between both groups as regard physical examination

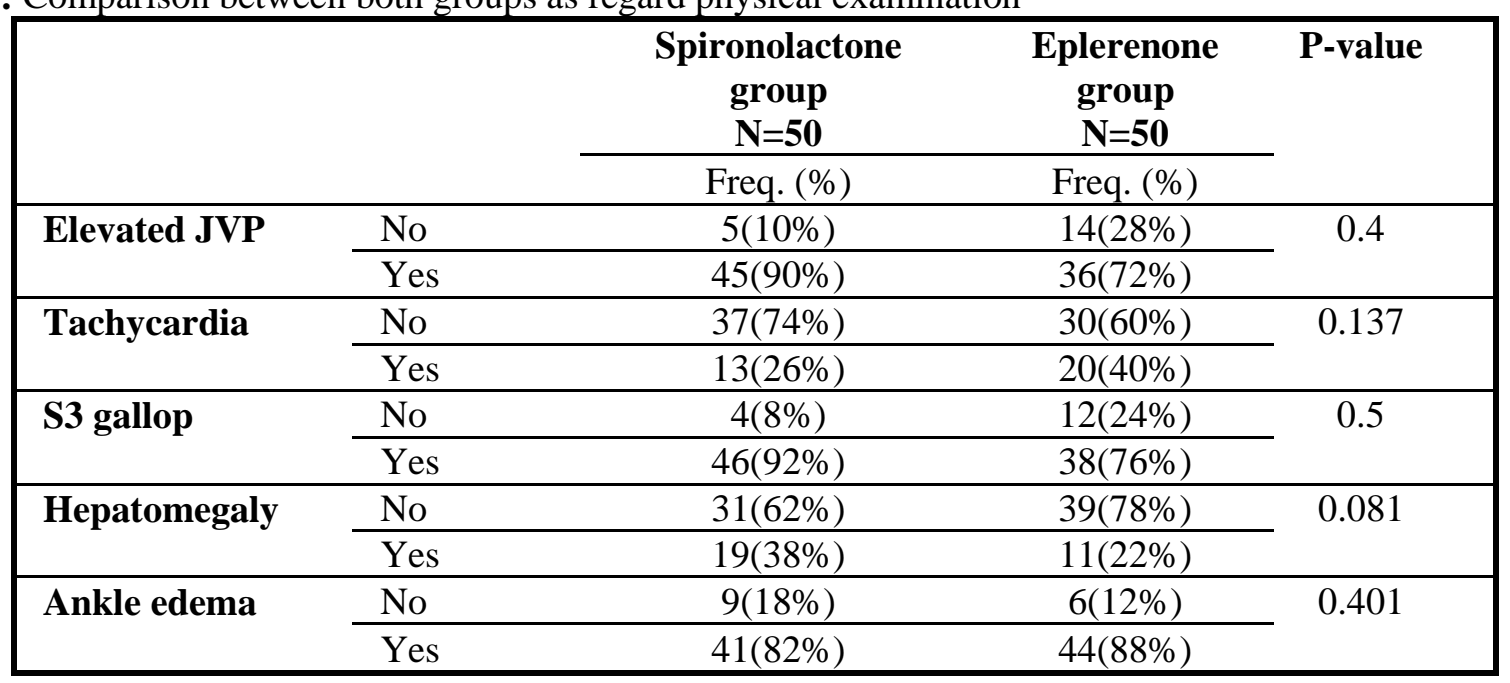

There were no significant differences between both groups as regard to pulmonary rales $(\mathrm{P}$ value $=0.22), \mathrm{X}$ ray cardiomegaly $(\mathrm{P}$ value $=0.76)$ and pleural effusion $(\mathrm{P}$ value $=0.54)$ while echocardiography data reveal no significant differences as regard to cardiac chamber dilatation $(\mathrm{P}$ value $=0.31)$, diastolic dysfunction $(\mathrm{P}$ value $=0.89)$, LV systolic function $(\mathrm{P}$ value $=0.43)$ and segmental wall motion abnormalities $(\mathrm{P}$ value $=0.19)($ Table 3,4$)$.

Table (3): X-ray finding of patients included in the study

\begin{tabular}{|llccc|}
\hline & & $\begin{array}{c}\text { Spironolactone } \\
\text { group } \\
\text { N=50 }\end{array}$ & $\begin{array}{c}\text { Eplerenone } \\
\text { group } \\
\text { N=50 }\end{array}$ & \multirow{2}{*}{ P-value } \\
\cline { 2 - 4 } & Freq. (\%) & Freq. (\%) & \\
\hline \multirow{2}{*}{$\begin{array}{l}\text { Pulmonary } \\
\text { Rales }\end{array}$} & Yes & $24(48 \%)$ & $30(60 \%)$ & 0.229 \\
\hline $\begin{array}{l}\text { X -Ray } \\
\text { cardiomegaly }\end{array}$ & No & $26(52 \%)$ & $20(40 \%)$ & 0.766 \\
\cline { 2 - 4 } Yes & $6(12 \%)$ & $7(14 \%)$ & 0.546 \\
\cline { 2 - 4 } Pleural effusion & No & $44(88 \%)$ & $43(86 \%)$ & \\
\cline { 2 - 4 } & Yes & $21(42 \%)$ & $24(48 \%)$ & \\
\hline
\end{tabular}


Table (4): Echocardiography data of the patients

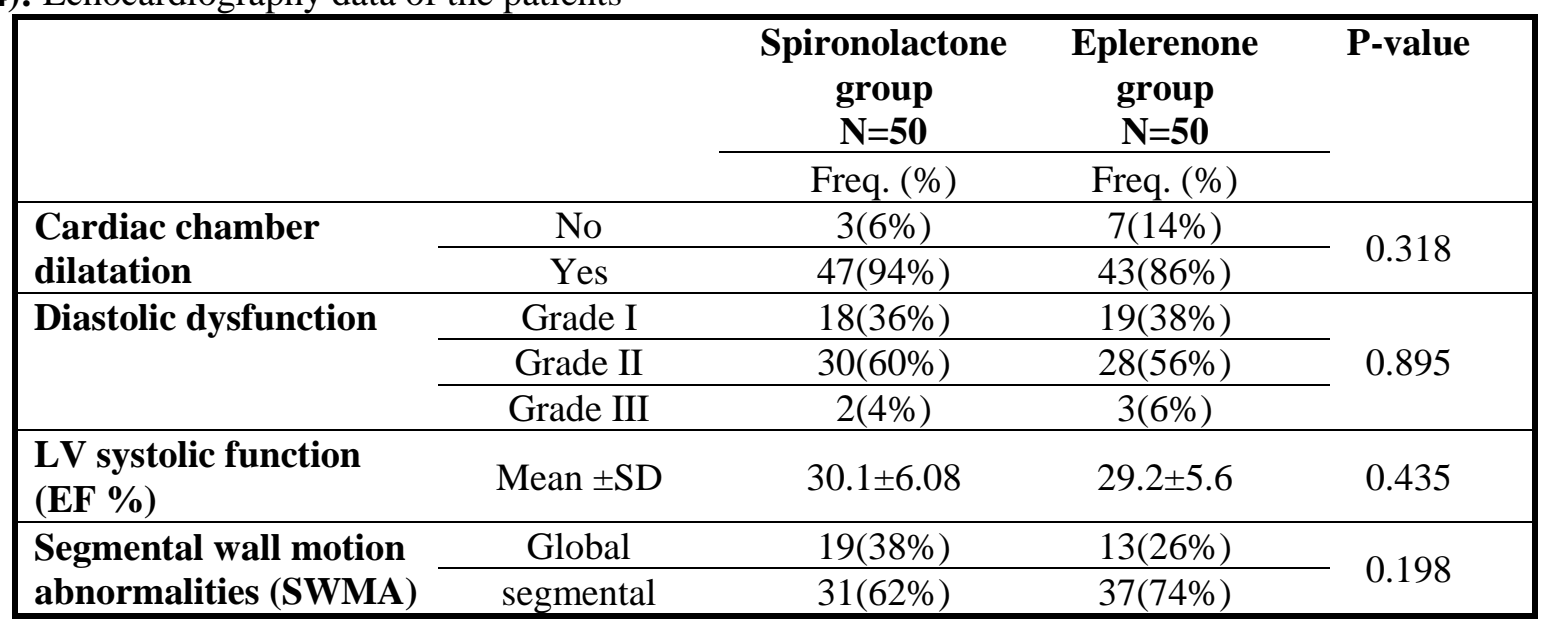

$$
\mathrm{EF}=\text { ejection fraction }
$$

Comparison of NYHA class follow up between both groups after three months of treatment shows significant improvement on each group separately with $\mathrm{P}$-value $=0.047$ on spironolactone group and $\mathrm{P}$ Value $=0.035$ on eplerenone group (Table 5).

Table (5): Follow up NYHA classification improvement

\begin{tabular}{|c|c|c|c|c|}
\hline Status & $\begin{array}{c}\text { ALL FU } \\
\text { PATIENTS } \\
(\mathrm{N}=75)\end{array}$ & $\begin{array}{c}\text { pironolactone Group } \\
(\mathbf{N}=\mathbf{3 4})\end{array}$ & $\begin{array}{c}\text { Eplerenone } \\
\text { Group } \\
(\mathbf{N}=41)\end{array}$ & $\begin{array}{l}P \text { value } \\
\text { among } \\
\text { groups }\end{array}$ \\
\hline No change & 26 & $14(41.1 \%)$ & $12(29.3 \%)$ & \multirow{3}{*}{0.582} \\
\hline Improved & 49 & $20(58.9 \%)$ & $29(70.7 \%)$ & \\
\hline \multicolumn{2}{|c|}{ P-value in each group } & $0.047 *$ & $0.035 *$ & \\
\hline
\end{tabular}

Comparison between both groups as regard levels of BNP on follow up showed very high significant $\mathrm{P}$ value $(<0.001)$ for each group (Table 6$)$.

Table (6): Follow up BNP

\begin{tabular}{|c|c|c|c|c|}
\hline \multirow{2}{*}{ BNP } & \multicolumn{2}{|c|}{ Spironolactone group } & \multicolumn{2}{c|}{ Eplerenone group } \\
\cline { 2 - 5 } & Baseline & Follow up & Baseline & Follow up \\
\hline \multirow{2}{*}{ Mean \pm SD } & $3545.2 \pm 3095.4$ & $1876.3 \pm 1895.1$ & $4616.3 \pm 2795.0$ & $3097.3 \pm 2499.5$ \\
\hline P-value & \multicolumn{2}{|c|}{$<0.001 * * *$} & \multicolumn{2}{c|}{$<0.001 * * *$} \\
\hline
\end{tabular}

Comparison between both groups as regard to increase of serum potassium levels: There were high significant differences on each group as on spironolactone group P value was $(0.001)$ while on eplerenone group P value was 0.008 (Table 7).

Table (7): Follow up potassium level

\begin{tabular}{|c|c|c|c|c|}
\hline \multirow[t]{2}{*}{ Potassium level } & \multicolumn{2}{|c|}{$\begin{array}{c}\text { Spironolactone group } \\
\qquad \mathrm{N}=34\end{array}$} & \multicolumn{2}{|c|}{$\begin{array}{l}\text { Eplerenone group } \\
\qquad \mathrm{N}=41\end{array}$} \\
\hline & Baseline & Follow up & Baseline & Follow up \\
\hline Mean \pm SD & $4.15 \pm 0.45$ & $4.48 \pm 0.43$ & $4.18 \pm 0.45$ & $4.34 \pm 0.38$ \\
\hline P-value & \multicolumn{2}{|c|}{$0.001^{* *}$} & \multicolumn{2}{|c|}{$0.008 * *$} \\
\hline
\end{tabular}

Comparison between both groups as regard gynecomastia in male patients there were significant differences in spironolactone group with $\mathrm{P}$-value $=0.028$ between groups $($ Table 8$)$. 
Table (8): Follow up gynecomastia in the male patients

\begin{tabular}{|c|c|c|c|}
\hline \multirow{2}{*}{$\begin{array}{c}\text { Gynecomastia } \\
\text { Number of males=79) }\end{array}$} & $\begin{array}{c}\text { Spironolactone group } \\
\mathbf{N = 3 9}\end{array}$ & $\begin{array}{c}\text { Eplerenone group } \\
\mathbf{N = 4 0}\end{array}$ & \multirow{2}{*}{ P-value } \\
\cline { 2 - 3 } & Freq. (\%) & Freq. (\%) & \\
\hline No & $32(82.2 \%)$ & $39(97.5 \%)$ & \multirow{2}{*}{$0.028 *$} \\
\hline Yes & $7(17.8 \%)$ & $1(2.5 \%)$ & \\
\hline
\end{tabular}

Comparison between both groups as regard body weight reduction after three months follow up there were very high significant differences on both groups with P-value less than 0.001 for each (Table 9).

Table (9): Follow up body weight

\begin{tabular}{|l|c|c|c|c|}
\hline \multirow{2}{*}{ Body weight } & \multicolumn{2}{c|}{ Spironolactone group } & \multicolumn{2}{c|}{ Eplerenone group } \\
\cline { 2 - 5 } & Baseline & Follow up & Baseline & Follow up \\
\hline Mean \pm SD & $85.3 \pm 13.6$ & $81.09 \pm 14.3$ & $81.1 \pm 13.4$ & $76.4 \pm 12.9$ \\
\hline P-value & \multicolumn{2}{|c|}{$<0.001 * * *$} & \multicolumn{2}{c|}{$<0.001 * * *$} \\
\hline
\end{tabular}

There were no significant differences between both groups with $\mathrm{P}$ value $(0.75)$ (Table 10).

Table (10): Worsening heart failure/need for rescue therapy

\begin{tabular}{|l|c|c|c|}
\hline & $\begin{array}{c}\text { Spironolactone } \\
\text { group } \\
\mathbf{N = 5 0}\end{array}$ & $\begin{array}{c}\text { Eplerenone group } \\
\mathbf{N = 5 0}\end{array}$ & $\begin{array}{c}\text { P-value of } \\
\text { comparison } \\
\text { between } \\
\text { groups }\end{array}$ \\
\hline $\begin{array}{l}\text { (Worsening heart failure/need for } \\
\text { rescue therapy }\end{array}$ & $6(12 \%)$ & $5(10 \%)$ & 0.750 \\
\hline 1-Deaths & $2(4 \%)$ & $2(4 \%)$ & 1.000 \\
\hline 2-Improved on IV diuretics & $3(6 \%)$ & $3(6 \%)$ & 1.000 \\
\hline $\begin{array}{l}\text { 3-Improved on IV inotropes and } \\
\text { diuretics }\end{array}$ & $1(2 \%)$ & $0(0 \%)$ & 0.317 \\
\hline
\end{tabular}

There were no significant differences between both groups in incidence of hyperkalemia although there were more patients had Hyperkalemia on spironolactone group (Table 11).

Table (11): Incidence of hyperkalemia with/out ECG changes:

\begin{tabular}{|l|c|c|c|}
\hline & $\begin{array}{c}\text { Spironolactone } \\
\text { group } \\
\mathbf{N = 5 0}\end{array}$ & $\begin{array}{c}\text { Eplerenone group } \\
\mathbf{N = 5 0}\end{array}$ & $\begin{array}{c}\text { P- value of } \\
\text { omparison between } \\
\text { groups }\end{array}$ \\
\hline $\begin{array}{l}\text { Incidence of hyperkalemia (serum } \\
\text { potassium above 5 mmol). }\end{array}$ & $11(22 \%)$ & $5(10 \%)$ & 0.103 \\
\hline $\begin{array}{l}\text { Range of serum Potassium level } \\
\text { Mean } \pm \text { SD (mmol) }\end{array}$ & $\begin{array}{c}5.1-6.7 \\
5.3 \pm 0.2\end{array}$ & $\begin{array}{l}5.2-6.4 \\
5.4 \pm 0.2\end{array}$ & 0.369 \\
\hline $\begin{array}{l}\text { Mean baseline creatinine level for all } \\
\text { hyperkalemic patients }\end{array}$ & $1.14 \pm 0.3$ & $1.22 \pm 0.4$ & 0.660 \\
\hline $\begin{array}{l}\text { Incidence of hyperkalemia with } \\
\text { ECG changes }\end{array}$ & $3(6 \%)$ & $1(2 \%)$ & 0.309 \\
\hline $\begin{array}{l}\text { Incidence of hyperkalemia (serum } \\
\text { potassium above 6mmol). }\end{array}$ & $2(4 \%)$ & $1(2 \%)$ & 0.558 \\
\hline
\end{tabular}

\section{DISCUSSION}

Heart is the target organ for Aldosterone, spironolactone and eplerenone (mineralocorticoid receptor antagonists) inhibits the aldosterone extraction through the heart in patients with $\mathrm{CHF}^{(8)}$.
However, to our knowledge, there are no head to head study of both agents had been done before on heart failure patients, it is obvious that the Pharmacological differences between spironolactone and eplerenone include the lower affinity of eplerenone for progesterone, androgen, and glucocorticoid 
receptors; and the presence of long-acting metabolites for spironolactone ${ }^{(9)}$.

Our study is a comparing between both spironolactone and eplerenone in improvement of BNP levels which reflect left ventricular systolic function, the reduction of BNP may have been due to blocking the mineralocorticoid receptors, which is known to be expressed in the human heart ${ }^{(10)}$.

The Level of BNP improved with both agents with $\mathrm{P}$ value $<0.001$ in each group.

One of other predictors of good prognosis in Heart failure patient were NYHA class which $\mathrm{P}$ value was 0.047 in spironolactone group and $P$ value 0.035 in eplerenone group after three months follow up.

Significant weight loss were in both MRA groups with $P$ value $<0.001$ on each group separately.

We confirmed that the both MRAs have a beneficial effect on heart failure patients in improving level of BNP, NYHA class and body weight Irrelevant to their class or heart failure symptoms without clinical statistical difference ${ }^{(\mathbf{1 0})}$.

Our findings have agreements with RALES Trial (Randomized Aldactone Evaluation Study) studied the effect of spironolactone Vs placebo on morbidity and mortality in patients with severe heart failure. The trial was discontinued early, because an interim analysis determined that spironolactone was efficacious. With $30 \%$ reduction in the risk of death among patients in the spironolactone group was attributed to a lower risk of both deaths from progressive heart failure and sudden death from cardiac causes. In addition, patients who received spironolactone had a significant improvement in the symptoms of heart failure, as assessed on the basis of the New York Heart Association functional class $(\mathrm{P}<0.001)^{(\mathbf{1 1})}$.

In EPHESUS (Eplerenone Post-Acute Myocardial Infarction Heart Failure Efficacy and Survival Study), the addition eplerenone to optimal medical therapy reduced morbidity and mortality in patients with AMI and LV dysfunction, which correlate with our study results ${ }^{(\mathbf{1 2})}$.

Regarding to undesirable effects, although both spironolactone and eplerenone had showed almost similar significant result in improving heart failure patients, the results were different in development of Hyperkalemia which was significant higher in spironolactone group as 11 cases of hyperkalemia (increase serum potassium level than more $5 \mathrm{mmol}$ ), while with eplerenone it was different, just 5 cases of developed hyperkalemia.

Clinical trials evaluating RAAS inhibitor therapy in patients with HFrEF, such as the Eplerenone in Mild Patients Hospitalization and Survival Study in Heart Failure (EMPHASIS-HF) and Randomized Aldactone Evaluation Study (RALES), severe hyperkalaemia (defined as serum potassium concentration $\geq 6.0 \mathrm{mEq} / \mathrm{l}$ ) has been reported in around $2.0-2.5 \%$ of participants. Hyperkalaemia of any degree has been reported in $10 \%$ of patients within a year of initiating RAAS blockade and is severe in approximately $1 \%$ of patients with diabetes. However, patients with baseline renal dysfunction or hyperkalaemia were excluded from these clinical trials ${ }^{(13)}$.

Analyses of the EMPHASIS-HF Study Subgroups (Eplerenone in Mild Patients Hospitalization And Survival Study in Heart Failure) In all high-risk subgroups, patients treated with eplerenone had an increased risk of potassium $>5.5$ $\mathrm{mmol} / \mathrm{l}$ but not of potassium $>6.0 \mathrm{mmol} / \mathrm{l}$, and Eplerenone was effective in reducing the primary composite endpoint in all subgroups ${ }^{(\mathbf{1 2})}$.

In June 2017 there were interesting metaanalysis including randomized, placebo-controlled trials reporting hyperkalemia on MRAs in patients after myocardial infarction or with chronic heart failure. They evaluated the truly MRA-related rate of hyperkalemia that represents hyperkalemia on MRA, corrected for hyperkalemia on placebo. Hyperkalemia was more frequently observed on MRA (9.3\%) against placebo (4.3\%) with $\mathrm{P}<0.0001$. In trials using eplerenone, hyperkalemia was documented in $5.0 \%$ on eplerenone and in $2.6 \%$ on placebo $(\mathrm{P}<.0001)$. In spironolactone trials, hyperkalemia was documented in $17.5 \%$ and in $7.5 \%$ of patients on placebo $(\mathrm{P}=.0001)^{(\mathbf{1 4})}$.

The good news are that two new potassiumbinding agents, patiromer and ZS-9, have been shown to be effective and safe for the treatment of hyperkalaemia, as well as the maintenance of normokalaemia, without dose reduction or discontinuation of RAAS inhibitors. In addition, the fast onset of ZS-9 action suggests that it may be useful in the treatment of acute hyperkalaemia. These agents may allow for dose optimization of RAAS inhibitors for the long-term maintenance and protection of the renal and cardiovascular system. For patients over 50 years, sodium polystyrene sulfonate (SPS), a cationexchange resin that binds potassium in the colon, has been used in the long term lowering of serum potassium levels ${ }^{(15)}$.

According to Gynecomastia, there were 7 male patients in spironolactone group suffered from gynecomastia by $17.8 \%$ of total male patients in group. While in Eplerenone group one case had suffered from gynecomastia with $2.5 \%$ of total male patients in the group. This considered much less gynecomastia incidence with eplerenone group (P-value $=0.028)$ between both groups.

In RALES trial Gynecomastia or breast pain was reported in $10 \%$ of men who were treated with spironolactone, as compared with $1 \%$ of men in the placebo group $(\mathrm{P}<0.001)^{(\mathbf{1 1})}$. 
In EPHESUS (Eplerenone Post-Acute Myocardial Infarction Heart Failure Efficacy and Survival Study), in comparisons with spironolactone, Eplerenone was associated with a lower incidence of gynecomastia and other sex hormone-related adverse effects $^{(12)}$.

\section{CONCLUSION}

MRA are important line of treatment in HF patients, eplerenone and spironolactone are both have good result in improving BNP level and improving NYHA classifications and patients weight loss.

There are differences in the tolerability profiles; spironolactone is associated with sexual side effects like appearance of gynecomastia in some male patients. Both agents produce increases in potassium concentrations, although the effect with spironolactone appears to be greater when both agents are administered at recommended doses.

\section{REFERENCES}

1. Struthers A, Krum H, Williams GH (2008):A Comparison of the Aldosterone- blocking Agents Eplerenone and Spironolactone. Clinical Cardiology, 31(4): 153-158.

2. Sánchez-Más J, Turpín MC, Lax A et al. (2010):Differential actions of eplerenone and spironolactone on the protective effect of testosterone against cardiomyocyte apoptosis in vitro. Revista Española de Cardiología (English Edition), 63(7): 779787.

3. Ye P, Yamashita T, Pollock DM et al. (2009):Contrasting effects of eplerenone and spironolactone on adrenal cell steroidogenesis. Hormone and Metabolic Research, 41(1): 35-39.

4. Roger S, Veronique L, Tolbert DS et al. (2004): Trends in heart failure incidence and survival in a communitybased population. JAMA., 292(3): 344-350.

5. Perk G, Tunick PA and Kronzon I (2007):NonDoppler two-dimensional strain imaging by echocardiography-from technical considerations to clinical applications. Journal of the American Society of Echocardiography,20(3):234-43.
6. Sahn DJ, DeMaria AN, Kisslo J et al. (1978): Recommendations regarding quantitation in $\mathrm{M}$ mode echocardiography: results of a survey of echocardiographic measurements. Circulation, 58(6): 1072-1083.

7. Jain N, Kotla S, Little BB et al. (2012):Predictors of hyperkalemia and death in patients with cardiac and renal disease. The American Journal of Cardiology, 109(10): 1510-1513.

8. Pitt B, Zannad F, Remme WJ et al. (1999): The effect of spironolactone on morbidity and mortality in patients with severe heart failure. N Engl J Med., 341:709-717.

9. Ziff OJ, Lane DA, Samra M et al. (2015): Safety and efficacy of digoxin: systematic review and meta-analysis of observational and controlled trial data. BMJ.,351:4451-9.

10. Zannad F, GattisStough W, Rossignol $P$ et al. (2012): Mineralocorticoid receptor antagonists for heart failure with reduced ejection fraction: integrating evidence into clinical practice. European Heart Journal, 33(22): 2782-2795.

11. Juurlink DN, Mamdani MM, Lee DS et al. (2004): Rates of hyperkalemia after publication of the Randomized Aldactone Evaluation Study. New England Journal of Medicine, 351(6): 543-551.

12. Pitt B, Remme W, Martinez $F$ et al. (2003):Eplerenone, a selective aldosterone blocker, in patients with left ventricular dysfunction after myocardial infarction. N Engl J Med., 348(14):1309-21.

13. Pitt B, Zannad FF, Neaton J et al. (2011): Evaluation of the efficacy and safety of RLY5016, a polymeric potassium binder, in a double-blind, placebo-controlled study in patients with chronic heart failure (the PEARLHF) trial. European Heart Journal, 32(7): 820-828.

14. Vukadinović $D$, Lavall $D$, Vukadinović AN et al. (2017):True rate of mineralocorticoid receptor antagonists-related hyperkalemia in placebo-controlled trials: A meta-analysis. American Heart Journal, 188: 99-108.

15. Scherr L, Ogden DA, Mead AW et al. (1961):Management of hyperkalemia with a cationexchange resin. New England Journal of Medicine, 264(3): 115-119. 